\title{
POPULACE POHŘBENÁ NA POHŘEBIŠTI TRIANGL V PRAZE- -STŘEŠOVICÍCH Z HLEDISKA REKONSTRUKCE STRAVY
}

\author{
DRAHOMÍRA FROLÍKOVÁ-KALISZOVÁ - SYLVA KAUPOVÁ
}

\begin{abstract}
Abstrakt: Raně středověké pohřebiště zkoumané v roce 2012 v Praze-Střešovicich poskytlo antropologický materiál z devatenácti dospělých jedinců, u nichž bylo možno antropologicky odhadnout pohlaví, pro zjištěni složeni jejich stravy pomoci analýzy stabilnich izotopů uhliku a dusiku v kostech. Jde o relativně reprezentativni soubor, nebot' tvoři 65,5\% ze všech dospělých jedinců nalezených na pohřebišti. Izotopové hodnoty uhliku a dusíku ukazuji na stravu suchozemského charakteru, bez významného podílu ryb a s relativně významným podilem prosa. Přestože hrobová výbava žretelně ukazuje na majetkové rozdily, nizká variabilita hodnot (zejména uhliku) je znakem jednotného potravního chování celé populační skupiny, což je pro tento soubor specifické. Hodnoty ziskané z lokality ležici v sousedství Pražského hradu byly srovnávány $s$ hodnotami zjištěnými jednak na pohřebištich v hradním areálu, jednak v jeho bezprostředním zázemí. Porovnáni hodnot ukazuje na socioekonomický gradient ve výživě vůči populaci Pražského hradu. Oproti dalším souborům ze zázemí přemyslovských center vykazuji Střešovice nadprůmérnou kvalitu výživy.
\end{abstract}

Kličová slova: zázemi Pražského hradu-pohřebiště - 10. století-izotopová analýza-strava.

\section{Population buried at the Triangle cemetery in Prague-Střešovice in the light of diet reconstruction}

Abstract: An early medieval burial site investigated in 2012 in Prague-Střěsovice provided anthropological material from the skeletal remains of nineteen adults, with anthropological determination of sex in order to study the composition of their diet by means of the analysis of stable carbon and nitrogen isotopes in the bones. It is a representative series as it contains $65.5 \%$ of all adults buried on the site. The isotope values of carbon and nitrogen point towards terrestrial diet, without a substantial proportion of fish and with a relatively high proportion of millet. Although grave goods clearly show differences in wealth, the low variability of the isotopic values (especially carbon) suggests a homogenous diet of the whole population group, which is specific for this sample. Isotopic values acquired from a location situated in a close distance to Prague Castle were compared with those from burial sites within the castle complex and with those in its hinterland. The comparison of the values points towards a socioeconomic gradient in the diet in comparison with the Prague Castle population. In contrast to other series from the hinterlands of Premyslid centres, Střešovice shows above-average diet quality.

Key words: Prague Castle hinterland - burial site - 10th century - isotope analysis - diet.

\section{Úvod}

Severozápadně od Pražského hradu, na úbočí táhlého hřbetu svažujícího se k jihu do údolí potoka Brusnice, pohřbívali v 9.-10. století lidé sídlící někde na katastru Střešovic, snad u kostela sv. Norberta (Tomková 2006, 212). Lokalita Triangl je na severní a východní straně ohraničena zářezy komunikací, na západní stávající zástavbou a na jižní svahem. V roce 2012 na ní proběhl předstihový výzkum ARÚ Praha. Zjistily jsme, že pohřebiště Triangl bylo částí velkého pohřebiště ničeného od 18. století těžbou hlíny pro strahovskou cihelnu (a možná už dřive při stavbě barokního opevnění, obr. 1). V 19. století byly z několika hrobů zachráněny části hrobové výbavy (souhrnně Tomková 2006a, 106-110). Poloha zničeného pohřebiště byla potvrzena nálezy jednotlivých předmětů z výsypky hlíny bývalé cihelny během archeologického výzkumu při stavbě tunelu Blanka (Tomková-Stránská 2011, 554). Část pohřebiště nejvýše ve svahu, která nebyla součástí těžební jámy cihelny, objevil I. Borkovský v roce 1924 (Borkovský 1969, 37; 1972, 41), avšak objevené hroby nedokumentoval (Sláma 1977, 127), odkryté kostry i s nálezy nechal překrýt térovým papírem a opět zasypat. Pohřebiště Triangl se 49 hroby je na základě hrobové výbavy a projevů pohřebních zvyklostí kladeno do 10. století. Výzkum byl publikován formou předběžné zprávy (Frolíková 2014), na niž navazovalo antropologické vyhodnocení kosterních pozůstatků (Stránská 2014a).

Pohřebiště bylo zařazeno do projektu Centra excelence GAČR 14-36938G „Středověká populace v centru a na venkově. Archeologie, bioarcheologie a genetika na pohřebištích Pražského 


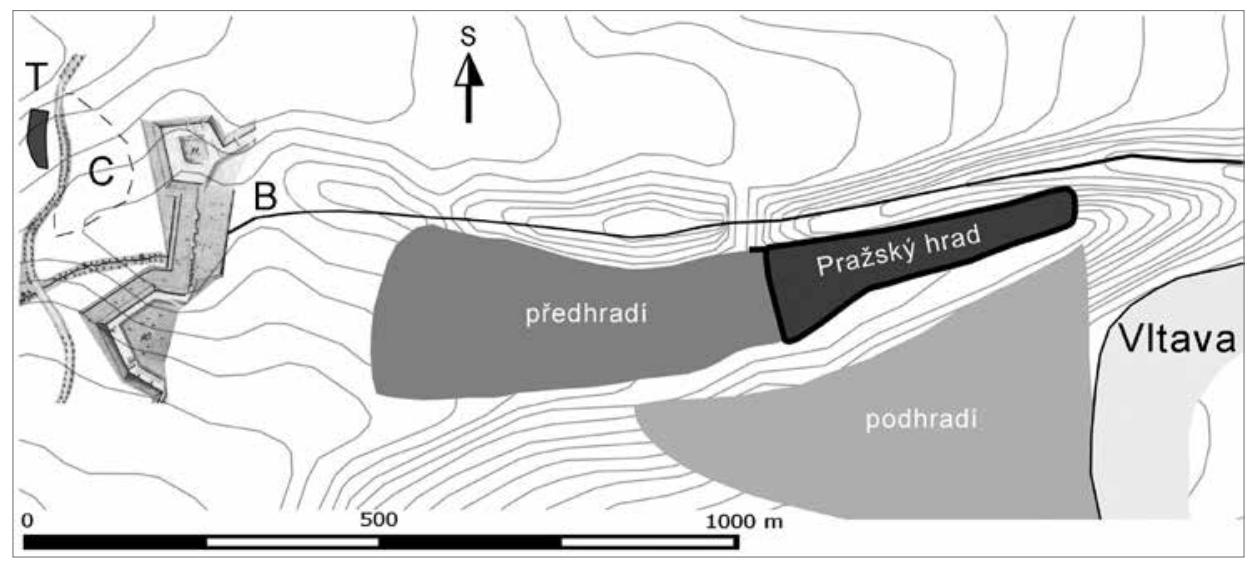

Obr. 1. Poloha pohřebiště Triangl (T) a jeho části zničené cihelnou (C) vzhledem k toku Brusnice (B) a Pražskému hradu. Upravila D. Frolíková.

Abb. 1. Prag-Střešovice. Lage des Gräberfeldes Triangel $(T)$ und seines durch eine Ziegelfabrik zerstörten Teils $(C)$ gegenüber dem Bach Brusnice (B) und der Prager Burg. Bearbeitet von D. Frolíková.

hradu, středních a východních Čech“. Jednotná metodika odběru a vyhodnocování vzorků má za cíl zjistit rozdíly mezi výživou mužů a žen z nejvyšší společenské vrstvy pohřbívající na Pražském hradě, výživou mužů a žen z jejich bezprostředního okolí a mužů a žen z venkovských pohřebišt'. Archeologická interpretace výsledků izotopové analýzy z jediného pohřebiště je předmětem našeho př́spěvku.

\section{Úvod do teorie izotopové analýzy}

Pro izotopovou analýzu výživy minulých populací je nejčastěji využívána kombinace hodnot stabilních izotopů uhlíku $\left(\delta^{13} \mathrm{C}\right)$ a dusíku $\left(\delta^{15} \mathrm{~N}\right)$ v kostním nebo zubním kolagenu (shrnutí např. Lee-Thorp 2008). Stabilní izotopy uhlíku umožňují detekovat konzumaci typů rostlin s odlišnou fotosyntentickou drahou. Takzvané C3 rostliny, mezi které patř́i většina rostlin mírného pásma, vykazují výrazně nižší hodnoty stabilních izotopů uhlíku než takzvané C4 rostliny, které jsou primárně adaptovány na suché a horké klima. Jedinou C4 rostlinou doloženou ve sledovaném období ve středoevropském kontextu je proso. Obdobně zvýšené hodnoty stabilních izotopů uhlíku pozorujeme též u ekosystémů mořských. Pro hodnoty stabilních izotopů dusíku je charakteristický nárůst o 3-5\% na každé úrovni potravního řetězce, tzn. mezi rostlinami a býložravci a býložravci a masožravci. V př́ípadě člověka, který je všežravec, pak dusík umožňuje určit podíl živočišné a rostlinné složky ve stravě. Vzhledem k tomu, že jak sladkovodní, tak mořské ekosystémy mají v průměru delší potravní řetězce než suchozemské (zjednodušeně řečeno, suchozemský potravní řetězec často tvoří jen tři články, rostliny - býložravci - masožravci, typický vodní řetězec tvoří rostliny - hmyz a zooplankton - drobní obratlovci - velké ryby vodní savci), projevuje se využívání těchto potravních zdrojů též ve zvýšení izotopových hodnot dusíku (Ambrose-Norr 1993; DeNiro-Epstein 1978; 1981; Lee-Thorp 2008; Minagawa-Wada 1984; Schoeninger-DeNiro 1984).

Ve středoevropském kontextu je nejčastěji pozorována strava založená na C3 rostlinách s variabilním podílem živočišných proteinů: pro tu jsou typické nižší hodnoty uhlíku i dusíku. Pokud jsou konzumovány C4 rostliny - tedy v našich podmínkách proso - nebo zvíŕata jimi krmená, dochází k nárůstu hodnot uhlíku, přičemž hodnoty dusíku zůstávají nízké (Kaupová a kol. 2018; Knipper et al. 2013; Reitsema et al. 2017; Teschler-Nicola et al. 2015). Jiným př́ípadem by byli jedinci a populace, u nichž jsou podstatnou složkou jídelníčku sladkovodní ryby; 
ty se projevují zvýšením hodnot dusíku při současně nízkých hodnotách uhlíku (KatzenbergWeber 1999). Případná konzumace mořských zdrojů by se pak projevila zvýšením hodnot obou izotopů (např. Vika-Theodoropoulou 2012).

Hlavní výhodou izotopové analýzy výživy je, že nám umožňuje získat přímé informace o stravě konkrétních jedinců. Další nezanedbatelnou výhodu představuje skutečnost, že izotopová měření lze provést i u relativně špatně zachovaných kosterních pozůstatků, kdy k provedení stačí zhruba půlgramový úlomek kompaktní kostní tkáně. Je ale třeba zmínit i některá omezení metody: i když technický pokrok umožňuje snižovat velikost vzorků, stále se jedná o metodu destruktivní. Je také nutné si uvědomit, že obraz výživy, který takto získáme, je velice hrubý v současnosti např́klad metoda nedokáže rozlišit mezi tím, zda jedinec konzumoval maso či mléko nebo vejce (a musíme tedy zůstat u souhrnného pojmu živočišné proteiny), a potraviny jako ovoce, zelenina, tuky a oleje jsou v izotopovém signálu kostního kolagenu prakticky neviditelné (Lee-Thorp 2008).

V kontextu raně středověké střední Evropy byla izotopová analýza výživy opakovaně použita zejména ke studiu dopadu změn souvisejících s nárůstem sociální komplexity společnosti na potravní chování jednotlivých skupin populace (Kaupová a kol. 2018; Knipper et al. 2013; Reitsema et al. 2017). Opakovaně tak byl prokázán rozdílný př́stup jednotlivých socioekonomických skupin raně středověkých populací (definovaných na základě místa pohřbu či jednotlivých vlastností pohřebního ritu) $\mathrm{k}$ potravním zdrojům zejména živočišného původu. Byl pozorován i nárůst těchto rozdílů v průběhu středověku (Hakenbeck et al. 2010). Dalším tématem je pak dopad křestanství na potravní chování. Výsledky těchto studií však naznačují, že výrazné ovlivnění potravního chování populací či jejich skupin postními regulemi bylo spíše otázkou období vrcholného a pozdního středověku, a bylo velmi vzácné před rokem 1000 (Barrett et al. 2008; Müldner 2009; Rutgers et al. 2009; Salamon et al. 2008).

Soubor pro izotopovou analýzu představují jedinci splňující dvě základní podmínky, a to dospělý věk a odhadnuté pohlaví. Podmínka věku byla stanovena ze dvou důvodů. Prvním je doposud ne zcela objasněný dopad procesu růstu na izotopové hodnoty. Výsledky dosavadních experimentů nejsou jednoznačné. V nedospělém věku je také pro kostní tkáň charakteristická rychlejší obnova, výživový signál zachycený v kosti tedy reflektuje výrazně kratší období než v dospělosti. Následkem toho může odrážet relativně krátkodobé výkyvy ve stravě jako například meziroční nebo dokonce sezónní variabilitu v dostupnosti potravních zdrojů (de Luca et al. 2012; Ponsard-Averbuch 1999; Waters-Rist-Katzenberg 2010). Je proto problematické porovnávat mezi sebou hodnoty nedospělých a dospělých jedinců, ale i nedospělých jedinců různého věku, a tedy s různou aktuální rychlostí růstu a kostní remodelace. Na rozdíl od věku pohlaví jedince prokazatelně neovlivňuje izotopové hodnoty jedince na fyziologické bázi. V řadě historických i současných populací byl však prokázán nerovný př́ístup jednotlivých pohlaví k potravním zdrojům, jenž může být reflektován v izotopových hodnotách (Hakenbeck et al. 2010; Kaupová a kol. 2018; Reitsema et al. 2010; Richards et al. 2006). Izotopové hodnoty jedinců bez odhadu pohlaví jsou tedy obtížně interpretovatelné. Uplatnění dvou výše zmíněných kritérií vedlo k významné redukci souboru na celkem 19 vzorků.

\section{Nálezová situace (tab. 1)}

Při archeologickém výzkumu bylo objeveno 49 hrobových jam raně středověkého pohřebiště, v nichž bylo pohřbeno 52 antropologicky hodnocených jedinců. Z nich bylo deset dospělých neurčitelného pohlaví, devět mužů, deset žen a 23 dětí. Jak vysvětlujeme výše, zkoumaný soubor tedy tvoří 19 vzorků, tj. 65,5\% z celkového množství dospělých jedinců (obr. 2). Při pohledu na plán pohřebiště je nápadné kolísání v orientaci hrobových jam od JJZ-SSV po Z-V. Na základě narušení staršího hrobu H 2 s orientací Z-V mladšími hroby 34 a 37 orientovanými JZ-SV se jeví jako možné vysvětlení rozdíl chronologický; tento závěr podporuje soustředění hrobů s orientací JZ-SV do jižní poloviny zkoumané plochy a jejich uspořádání do řad na rozdíl od řídce rozmístěných hrobů západovýchodní orientace, které chybějí v nejjižnějším cípu plochy. 


\begin{tabular}{|c|c|c|c|c|c|}
\hline č. hr. & orientace & $\begin{array}{l}\text { rozměry hrobové jámy } \\
\qquad(\mathrm{v} \mathrm{cm})\end{array}$ & $\begin{array}{l}\text { úprava hrobové jámy, stav - } \\
\text { porušení hrobu (rozměry v cm) }\end{array}$ & pohlaví & výbava \\
\hline 3 & 240 & š. $70-58$, hl. $20-25$ & ukopaná horní část s lebkou & muž & \\
\hline 5 & 255 & $220 \times 64 \times 20-25$ & $\begin{array}{l}\text { neúplné obložení kameny, } \\
\text { plocha } 200 \times 64\end{array}$ & muž & \\
\hline 6 & 255 & $216 \times 65-75 \times 30-40$ & porušený hrudník & žena & pár esovitých záušnic, nožík \\
\hline 8 & 220 & š. 40 , hl. 10 & jen dolní polovina & žena & $?$ \\
\hline 11 & 240 & $237 \times 85-78 \times 50$ & dřevo $210 \times 50-45$ & muž & \\
\hline 12 & 250 & $200 ? \times 80-50 ? \times 25$ & porušen výkopem 1924 & muž & \\
\hline 17 & 260 & $220 \times 70-80 \times 30$ & $\begin{array}{l}\text { zahloubena v pravěkém } \\
\text { objektu; delší }\end{array}$ & žena & $\begin{array}{c}3 \text { esovité záušnice, korálek } \\
\text { a nožík }\end{array}$ \\
\hline 21 & 250 & $212 ? \times 100 ? \times 55$ & $\begin{array}{l}\text { porušen výkopem } 1924, \\
\text { stopy dřeva }\end{array}$ & žena? & \\
\hline 22 & 230 & hl. $30 \mathrm{~cm} ?$ & $\begin{array}{l}\text { čtyřnásobný pohřeb, porušen } \\
\text { výkopem } 1924\end{array}$ & muž & \\
\hline 23 & 240 & š. 55, hl. 10 & $\begin{array}{l}\text { porušen výkopem } 1924, \\
\text { v pravěkém objektu }\end{array}$ & žena & 2 esovité záušnice, nožík \\
\hline 27 & 250 & $217 \times 75 ? \times 30$ & $\begin{array}{l}\text { porušen výkopem } 1924, \\
\text { kamenné obložení }\end{array}$ & žena & \\
\hline 28 & 235 & $220 ? \times 60 \times 15$ & narušena kořeny stromu & muž & \\
\hline 33 & 230 & $194 ? \times 59 / 70 \times 55$ & $\begin{array}{l}\text { křemenec u každé paže, jeden } \\
\text { u pravého chodidla }\end{array}$ & žena & nůž \\
\hline 36 & 230 & $232 \times 93 \times 55$ & obrys rakve $205 \times 43 / 48$ & muž & nůž \\
\hline 40 & 225 & $250 \times 75-95 x \times 23-32$ & obrys rakve $220 \times 45-50$ & muž & nůž,ostruhy \\
\hline 45 & 265 & $194 \times 45 \times 37$ & schodová úprava s kameny & žena & \\
\hline 47 & 225 & $247 \times 60-81 \times 40-45$ & & žena & $\begin{array}{c}16 \text { záušnic, } 3 \text { prstýnky, } \\
\text { náhrdelník, } 2 \text { nože }\end{array}$ \\
\hline 48 & 225 & $240 \times 80 \times 38$ & dřevo $208 \times 47,1$ kámen & žena & \\
\hline 50 & 210 & d. přes 180 , hl. $0-15$ & $\begin{array}{l}\text { dřevo, chodidla a část bérců } \\
\text { odř́iznuty }\end{array}$ & muž & $?$ \\
\hline
\end{tabular}

Tab. 1. Praha-Střešovice. Analyzované hroby s archeologickými charakteristikami. Tab. 1. Prag-Stř̌̌šovice. Analysierte Gräber mit archäologischen Charakteristika.

Přestože definitivní ověření chronologického významu orientace bude možné až po zpracování veškeré hrobové výbavy (dosud probíhá její konzervace a chemické analýzy), nemohly jsme pominout možný časový aspekt ve stravě pohřbené populace.

Z hlediska možného projevu sociálního statusu pohřbených jsme braly v úvahu jednak hrobovou výbavu a jednak náročnost úpravy hrobové jámy. Převažovaly pohřby bez výbavy (H 3 , $5,8,11,12,21,22$ a , 27, 28, 45, 48, 50). Pohřby s výbavou (H 6, 17, 23, 33, 36, 40, 47) obsahovaly nůž, šperky ze stř́ibra, skla nebo polodrahokamů a $\mathrm{v}$ jednom případě železné ostruhy s delším bodcem (H 40). Je však třeba vzít v úvahu, že byla-li zničená horní část hrobu ženy (H 8), nevíme, zda neměla šperky, a naopak ve zničené dolní části hrobu muže (H 50) mohly být ostruhy (tab. 1, vyjádřeno otazníkem). Na pohřebišti Triangl nemá smysl vypočítávat kubatury hrobových jam, ze všech 49 jich bylo neporušených 27 , zatímco 22 hrobů bylo poškozených; mezi zkoumanými 19 hroby je poškozených devět. V tab. 1 proto uvádíme zjištěné rozměry v úrovni dna hrobové jámy, z nichž lze vyčíst, zda hrobová jáma má rozměry odpovídající velikosti pohřbeného těla nebo byla nadměrně velká. Vyjdeme-li od relativní hloubky jako veličiny zjistitelné u všech hrobů (byla měřena od povrchu podloží), vidíme největší zahloubení $55 \mathrm{~cm} \mathrm{u} \mathrm{H} \mathrm{21,33}$ 


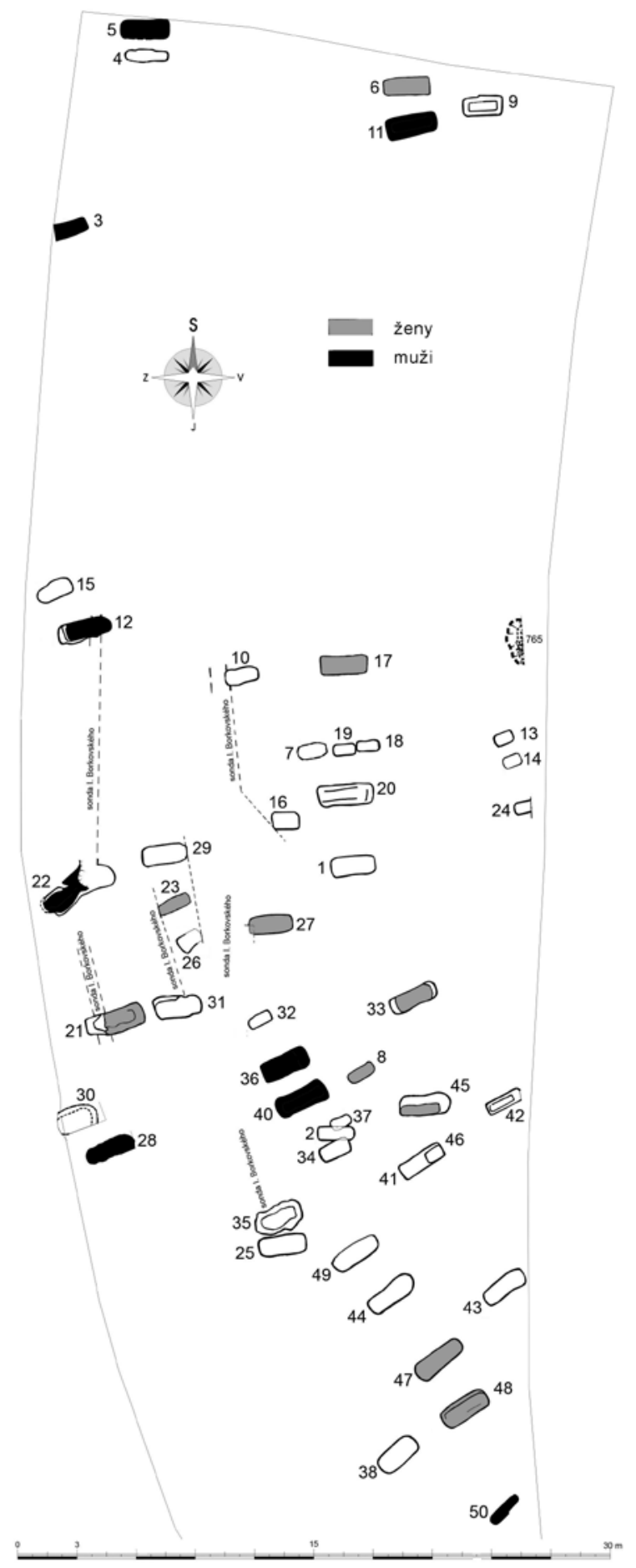

Obr. 2. Praha-Střešovice. Hroby, z nichž byly odebírány vzorky na izotopovou analýzu. Upravila D. Frolíková.

Abb. 2. Prag-Stř̌š̌ovice. Gräber, denen die Proben für die Isotopenanalyse entnommen wurden. Bearbeitet von D. Frolíková. 
a 36, následované H 11 hlubokým $50 \mathrm{~cm}$ a H 6, 17, 22, 27, 40, 45, 47 a 48 hlubokými 30-45 cm. Šiřky neporušených hrobových jam bez př́ítomnosti dřeva se pohybují mezi 58 a $80 \mathrm{~cm}$, v hrobech s výdřevou nebo rakví mezi 75-95 cm (přítomnost dřeva v hrobě se projevovala nanejvýš v podobě zbytků, z nichž nelze usuzovat na původní podobu). Zachovalé hrobové jámy dospělých jedinců měřily na délku obvykle 200 až $220 \mathrm{~cm}$, hroby s výdřevou/rakví byly dlouhé 232 až $250 \mathrm{~cm}$. Zařazení se vymyká $H 45$, v němž kostra ležela ve schodovitě zúžené spodní části hrobu, jehož svrchní část měřila $256 \times 91-100 \mathrm{~cm}$. Pro srovnání si všímáme i vložení kamenů do hrobu, které ale představuje nenáročný způsob úpravy hrobové jámy v H 5, 27, 33, 45, 48. Shrnuto, pohřeb v rakvi nebo do jámy s výdřevou vyžadoval vykopat rozměrnější hrobovou jámu, zatímco vložení kamenů do hrobové jámy (H 5, 27 a 33) větší hrobovou jámu nevyžadovalo (hrob 45 představuje neinterpretovatelnou výjimku). Korelace mezi velikostí hrobu a použitím dřeva je zřetelná, srovnatelné rozměry měl z hrobů bez použití dřeva jen hrob ženy H $47 \mathrm{~s}$ nejbohatší výbavou. Hluboký H 33 je zvláštní tím, že v něm nebyly kameny místního původu jako ve všech ostatních hrobech na Trianglu, nýbrž přinesené křemence; snad je možno považovat za zvláštnost i to, že je v něm pohřbená žena s nožem, ale bez šperku (ovšem antropologický posudek udává klasifikaci „spíše žena“ - Stránská 2014). Relativně hlubší hrobovou jámu měly ženy pohřbené se šperky v H $6, \mathrm{H} 17$. Z hrobů s výbavou jedině poškozený H 23 je mělký a bez zachycené úpravy hrobové jámy. Ve čtyřhrobu 22 měl spodní jedinec neurčitelného pohlaví nůž, vzorky však byly odebrány z kostry muže bez výbavy. Hraniční hloubky $30 \mathrm{~cm}$ ještě dosáhl H 27 bez výbavy, s porušenou hrobovou jámou.

\section{Izotopová analýza}

Cílem tohoto př́spěvku bylo studium variability stravy v rámci daného souboru ve vztahu k biologickým, socioekonomickým i chronologickým parametrům. Byly tedy zkoumány rozdíly ve stravě podle pohlaví a dožitého věku, možná změna stravování během sta let trvání pohřebiště, a konečně vztah mezi potenciálními ukazateli socioekonomického postavení a kvalitou stravy. Konkrétně jsme testovaly hypotézu, že jedinci pohřbení v hrobech s bohatší výbavou, prŕípadně v náročně upravené hrobové jámě, u nichž se předpokládá, že pocházeli z bohatších rodin, byli i lépe živeni. Indikátorem kvality stravy, který je možno sledovat s pomocí analýzy stabilních izotopů, je zejména podíl živočišných proteinů ve stravě. Rozdíly v konzumaci živočišných proteinů na základě prŕslušnosti $\mathrm{k}$ socioekonomické skupině byly pozorovány $\mathrm{v}$ řadě evropských středověkých populací (např. Hakenbeck 20013; Kaupová a kol. 2018; Kjellström a kol. 2009; Yoder 2012).

Pro izotopovou analýzu výživy bylo odebráno přibližně $250 \mathrm{mg}$ kostní tkáně žebra (případně, pokud žebra nebyla zachována, článku prstu). Kolagen byl extrahován metodou dle Longina (1971) v modifikaci dle Bocherense (1992). Izotopová měření (EA-IRMS) byla provedena v laboratoři Iso-Analytical Ltd., Crewe, Velká Británie. Směrodatná odchylka při opakovaných měřeních s použitím několika laboratorních standardů (IA-R042: hovězí játra, L-alanin, IA-R006: třtinový cukr a IA-R046: síran amonný) činila méně než $0,1 \%$ pro $\delta^{13} \mathrm{C}$ i $\delta^{15} \mathrm{~N}$. Tyto standardy slouží k ověření přesnosti měření a ke kalibraci hodnot vůči mezinárodně uznávaným standardům poskytovaným Mezinárodní agenturou pro atomovou energii (IAEA) ve Vídni. Statistická analýza zahrnovala vzhledem k velikosti souboru Mann-Whitneyův test, a to jeho exaktní variantu pro malé soubory. $Z$ tohoto důvodu také nebylo možné zařazení vícefaktorové statistické analýzy. Všechny testy byly provedeny pro celý soubor i - pokud to počet jedinců umožňoval pro jednotlivá pohlaví.

\section{Výsledky a diskuse}

Všechny vzorky splňovaly kritéria pro dobrou zachovalost - výtěžek kolagenu, obsah dusíku, uhlíku i jejich vzájemný poměr v rámci definovaných intervalů (DeNiro 1985; Van Klinken 1999), a získaná data tedy bylo možné považovat za hodnověrná. Hodnoty stabilních izotopů 
uhlíku se pohybovaly v rozmezí $-19,0 \%$ až $-18,2 \%$ (medián $-18,6 \%$ o). Hodnoty stabilních izotopů dusíku se pak pohybovaly v rozmezí 7,3 \%o až 10,1 \%o (medián 9,7\%o). Z hlediska obecné charakteristiky stravy lze říci, že se jedná o soubor s 1) detekovatelným podílem prosa $\mathrm{v}$ jídelníčku, 2) průměrným podílem živočišných proteinů ve stravě (z hlediska stř̌edověkých populací) a 3) vysokou homogenitou stravy (zejména z hlediska hodnot $\delta^{13} \mathrm{C}$ ). Detailní porovnání výživy střešovického souboru v rámci raně středověkých Čech a zahrnutí do širšího evropského kontextu je předmětem jiné práce (Kaupová a kol. v tisku), v níž jsou př́stupná i kompletní izotopová data souboru. Předmětem tohoto př́spěvku je naopak detailní analýza výživy v rámci sledovaného souboru (tab. 2).

\begin{tabular}{|c|c|c|c|c|c|c|}
\hline & \multicolumn{2}{|c|}{$\mathrm{n}$} & & \multicolumn{3}{|c|}{$\mathrm{p}$} \\
\hline & Muži & Ženy & & Všichni & Muži & Ženy \\
\hline \multirow{2}{*}{ Pohlaví } & \multirow{2}{*}{9} & \multirow{2}{*}{10} & $\delta^{13} \mathrm{C}$ & 0,315 & $\mathrm{x}$ & $\mathrm{x}$ \\
\hline & & & $\delta^{15} \mathrm{~N}$ & 0,278 & $\mathrm{x}$ & $\mathrm{x}$ \\
\hline \multirow{2}{*}{ Věk: mladší/starší 35 let } & \multirow{2}{*}{$3 / 6$} & \multirow{2}{*}{$1 / 9$} & $\delta^{13} \mathrm{C}$ & 0,185 & 0,547 & NS \\
\hline & & & $\delta^{15} \mathrm{~N}$ & 0,357 & 0,381 & NS \\
\hline \multirow{2}{*}{ Hrobová výbava: př́itomnost/absence } & \multirow{2}{*}{$2 / 7$} & \multirow{2}{*}{$5 / 5$} & $\delta^{13} \mathrm{C}$ & 0,773 & NS & 0,421 \\
\hline & & & $\delta^{15} \mathrm{~N}$ & 0,045 & NS & 0,056 \\
\hline \multirow{2}{*}{ Vnitřní úprava: ano/ne } & \multirow{2}{*}{$5 / 4$} & \multirow{2}{*}{$5 / 5$} & $\delta^{13} \mathrm{C}$ & 0,083 & 0,111 & 0,413 \\
\hline & & & $\delta^{15} \mathrm{~N}$ & 0,274 & 0,556 & 0,556 \\
\hline \multirow{2}{*}{ Vnitřní úprava: dřevo/ostatní } & \multirow{2}{*}{$4 / 5$} & \multirow{2}{*}{$2 / 8$} & $\delta^{13} \mathrm{C}$ & 0,151 & 0,286 & NS \\
\hline & & & $\delta^{15} \mathrm{~N}$ & 0,103 & 0,556 & NS \\
\hline
\end{tabular}

Tab. 2. Praha-Střešovice. Výsledky statistické analýzy vztahu mezi izotopovými hodnotami a jednotlivými biologickými a socioekonomickými indikátory. Výsledky statisticky signifikantní na pětiprocentní hladině významnosti tučně; $\mathbf{n}$ - počet jedinců, $p$ - hodnota statistického testu; NS - statistická analýza nebyla provedena vzhledem k nízkému počtu jedinců v některé ze skupin.

Tab. 2. Prag-Stř̌ešovice. Ergebnisse der statistischen Analyse der Beziehung zwischen den Isotopwerten und den jeweiligen biologischen und sozioökonomischen Indikatoren. Statistisch signifikante Ergebnisse auf 5-Prozent-Niveau sind fett gekennzeichnet; $\mathbf{n}$ - Anzahl der Individuen, p - Wert des statistisches Test; NS - im Hinblich auf die geringe Anzahl von Individuen in einigen Gruppen wurde keine statistische Analyse durchgeführt.

Ve studovaném souboru nebyly nalezeny rozdíly ve výživě na podkladě biologických charakteristik (věku a pohlaví). Muži vykazovali mírně vyšší hodnoty $\delta^{15} \mathrm{~N}$ ukazující na vyšší podíl živočišných proteinů ve stravě (medián 10,0 \%) než ženy (medián 9,4 \%), pozorovaný rozdíl ale nebyl statisticky významný (obr. 3A). Nebyl též prokázán rozdíl ve stravě jedinců zemřelých do 35 let věku a jedinců starších 35 let. Tento výsledek se opakoval i v redukovaném souboru mužů. $\mathrm{V}$ případě žen nebylo možné statistické vyhodnocení provést vzhledem k tomu, že v celém souboru byla pouze jedna žena mladší 35 let. Její izotopové hodnoty nijak nevybočovaly z rámce variability souboru.

Při porovnání hrobů z hlediska chronologického nebyl prokázán signifikantní rozdíl ve výživě. Jak je patrné z obrázku 3B, na této situaci nic nemění ani vyčlenění skupiny hrobů s hraniční orientací ZSZ-VJV. Zdá se tedy, že strava populační skupiny se v průběhu užívání pohřebiště nezměnila, přinejmenším co se týče parametrů sledovatelných s pomocí izotopové analýzy.

Z porovnání výživy jedinců pohřbených s výbavou a bez výbavy (obr. 3C) plyne, že zatímco hroby bez výbavy mají variabilní hodnoty a pohybují se v rámci celého rozmezí hodnot, jedinci pohřbení s výbavou vykazovali sice více homogenní, ale překvapivě v průměru nižší hodnoty $\delta^{15} \mathrm{~N}$ (a tedy nižší podíl živočišných proteinů ve stravě, medián $9,1 \%$ ) než jedinci pohřbení bez výbavy (medián 10,0 \%). Tento trend byl patrný i v redukovaném souboru žen (u mužů nebylo 

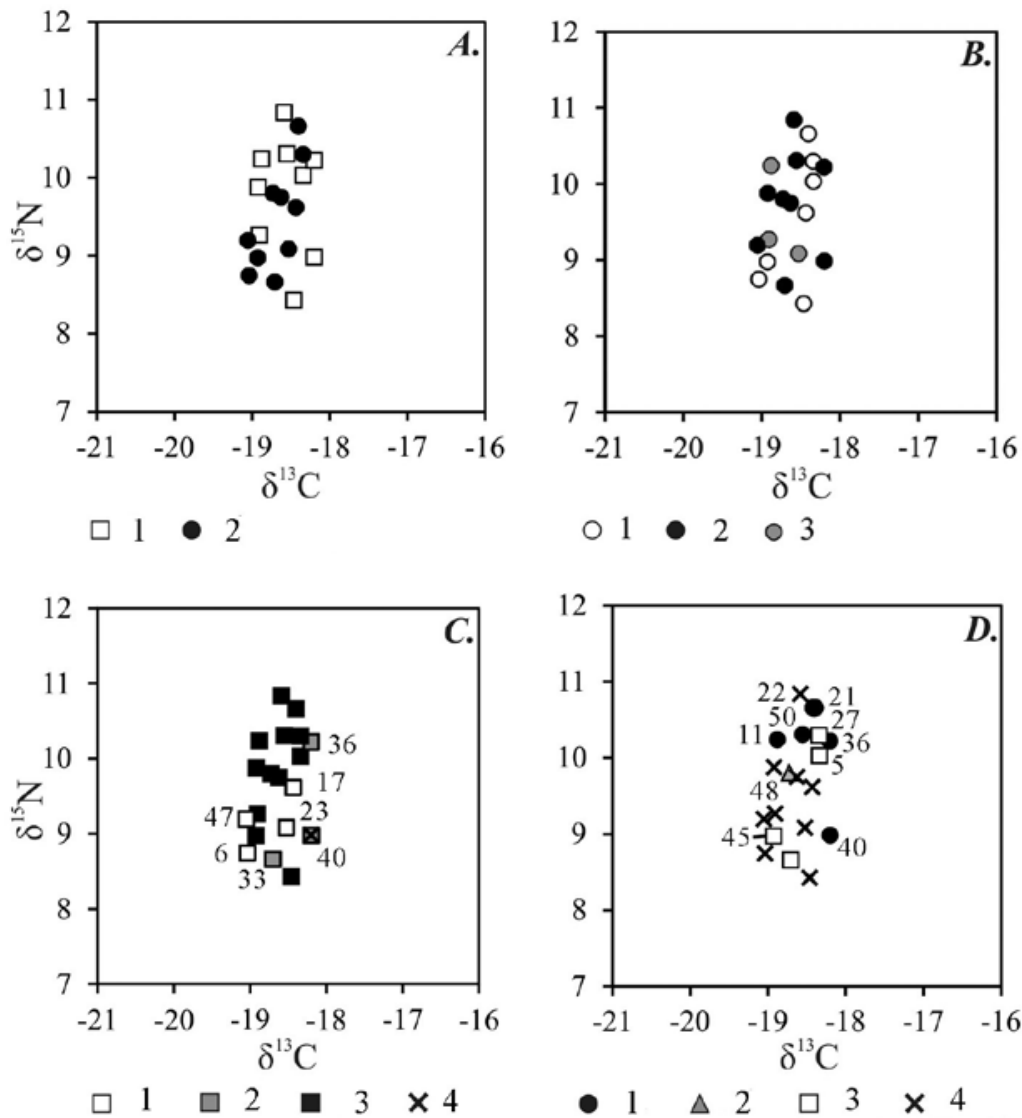

Obr. 3. Izotopové hodnoty souboru z pohřebiště Triangl. A - ve vztahu k pohlaví, 1 - muži, 2 - ženy; B - ve vztahu k orientaci hrobu související s relativní chronologií pohřebiště, 1 - orientace Z-V (starší), 2 - orientace JZ-SV až JJZ-SSV (mladší), 3 - orientace ZJZ-VSV; C - ve vztahu k př́tomnosti a kvalitě hrobové výbavy, 1 - šperk, 2 - nůž, 3 - bez výbavy, 4 - ostruhy; D - ve vztahu k př́tomnosti a typu vnitřní hrobové konstrukce či rakve, 1 - dřevo, 2 - kámen i dřevo, 3 - kámen, 4 - bez konstrukce. Vyšší hodnota na ose $x\left(\delta^{13} C\right)$ ukazuje na vyšší podíl prosa, vyšší hodnota na ose y $\left(\delta^{15} N\right)$ pak na vyšší podíl živočišných proteinů (masa a mléka) ve stravě.

Abb. 3. Die Isotopwerte vom Gräberfeld Triangel. A - im Bezug zum Geschlecht, 1 - Männer, 2 - Frauen; B - im Bezug zur mit der relativen Chronologie des Gräberfeldes zusammenhängenden Graborientierung, 1 - W-O-Orientierung (ältere), 2 - SW-NO-Orientierung bis SSW-NNO-Orientierung (jüngere), 3 - WSW-ONO-Orientierung; C - im Bezug auf Vorhandensein und Qualität von Grabbeigaben, 1 - Schmuck, 2 - Messer, 3 - ohne Beigaben, 4 - Sporen; D - im Bezug auf Vorhandensein und Typ der inneren Grabkonstruktion bzw. eines Sarges, 1 - Holz, 2 - Stein und Holz, 3 - Stein, 4 - ohne Konstruktion. Der höhere Wert auf der $x$-Achse $\left(\delta^{13} C\right)$ deutet auf einen höheren Hirseanteil, der höhere Wert auf der y-Achse $\left(\delta^{15} \mathrm{~N}\right)$ dann auf einen höheren Anteil an tierischen Proteinen (Fleisch und Milch) in der Ernährung hin.

možné vzhledem k celkově nízkému počtu hrobů s výbavou analýzu provést). Výsledky statistických testů se pohybovaly v blízkosti pětiprocentní hladiny významnosti (tab. 2). Obdobných výsledků jsme dosáhly, pokud jsme vydělily pouze skupinu hrobů obsahujících u žen šperk, u mužů ostruhy. Z tohoto trendu se nevymykají ani jedinci s výjimečnou (z hlediska daného souboru) hrobovou výbavou. Podprůměrnou hodnotu $\delta^{15} \mathrm{~N}$ vykazoval hrob $47 \mathrm{~s}$ nejbohatší ženskou výbavou (16 záušnic, 3 prsteny, 14 korálků, 2 nože; $\delta^{15} \mathrm{~N}=9,2 \%$ ) i mužský hrob 40 s nálezem ostruh $\left(\delta^{15} \mathrm{~N}=9,0 \%\right)$. V př́padě muže z hrobu 40 je nutné zmínit patologický nález zánětlivých změn na vnitřní straně žeber jako důsledek déletrvajícího vnitrohrudního zánětlivého procesu (Stránská 2014a, 338). Ovlivnění izotopových hodnot, at' už přímým (změny metabolismu, 
problémy s př́ijmem či trávením potravy), či nepřímým způsobem (chorobou způsobené nechutenství, změna stravovacích návyků vlivem léčebných praktik či snížená schopnost jedince obstarat si kvalitní stravu) je však relativně nepravděpodobné vzhledem k tomu, že kostní vzorky dospělých osob zachycují výživový signál z dlouhého období života (řádově desítky let, Hedges a kol. 2007). I když studie zabývající se izotopovou analýzou patologických nálezů jsou doposud relativně řídké, žádná z nich neprokázala systematický dopad chronického onemocnění s kostním projevem na izotopové hodnoty, pokud se vzorkování vyhnulo př́mo patologické tkáni (např. Linderholm-Kjellström 2011; Olsen a kol. 2014). Jedinci pohřbení s hrobovou výbavou tedy nekonzumovali během života kvalitnější stravu (přinejmenším z hlediska podílu živočišných proteinů).

Při testování vztahu mezi př́ítomností konstrukce (kamenné či dřevěné) vůči pohřbům $\mathrm{v}$ prosté hrobové jámě jsou (obr. 3D) patrné vyšší hodnoty $\delta^{15} \mathrm{~N}$ u jedinců pohřbených $\mathrm{v}$ hrobech $\mathrm{s}$ vnitřní konstrukcí (medián 10,1 \%) než u pohřbů v prosté jámě (medián 9,2\%). Tento trend je patrný u obou pohlaví, nicméně výsledky statistických testů nejsou signifikantní. Bylo provedeno též alternativní testování mezi skupinou hrobů s přítomností dřeva (jako náročnější formou úpravy hrobové jámy) a zbylými hroby (tedy s přítomností kamene či hrobové jámy bez úpravy). Pokud je vydělena pouze skupina hrobů s náročnější úpravou hrobové jámy v podobě rakve či výdřevy, je popisovaný trend patrnější: s výjimkou hrobu 40 všichni jedinci vykazují hodnoty vyšší než medián daného souboru. Nicméně ani v prrípadě muže z H 40 výsledek testu nebyl signifikantní na pětiprocentní hladině významnosti $(\mathrm{p}=0,103)$.

Jediným výsledkem blížícím se statistické signifikanci na pětiprocentní hladině významnosti z hlediska hodnot stabilních izotopů uhlíku jsou pak mírně vyšší hodnoty $\delta^{13} \mathrm{C}$ u jedinců z hrobů s vnitřní konstrukcí (medián -18,5\%) oproti hrobům bez konstrukce (medián -18,8 \%o). Vzhledem k nízké variabilitě celého souboru z hlediska hodnot $\delta^{13} \mathrm{C}$ je však pozorovaný rozdíl spíše reliktem malé velikosti souboru bez biologické signifikance.

\section{Závěry}

Pohřebiště Triangl nepatřilo k pohřebištím špiček tehdejší společnosti, přesto na něm pozorujeme rozdíly: hroby se stříbrnými šperky oproti hrobům bez výbavy, hroby s nadměrně velkou hrobovou jámou s výdřevou nebo rakví oproti hrobům s jámou velikosti přiměřené tělu pohřbeného, hroby mělké i relativně hluboké, hroby s vloženými kameny. Analýza výživy však neprokázala statisticky signifikantní vztah mezi kvalitou stravy a hrobovou výbavou jako potenciálním ukazatelem socioekonomického postavení jedince. Hrob 47 s nejbohatší ženskou výbavou i hrob 40 muže s ostruhami patří do spodní poloviny podle podílu konzumace živočišných proteinů v rámci analyzovaného vzorku z pohřebiště, naopak hroby bez výbavy spolu s H 36 s nožem vykazují nejvyšší podíl proteinů ve stravě. Situace se jeví jinak, podíváme-li se na vztah mezi úpravou hrobové jámy a kvalitou výživy: hroby se zaznamenanou př́tomností dřeva (s výjimkou hrobu 40) se shlukují v horní polovině grafu, spolu s nimi je tam porušený čtyřhrob H 22. Z archeologizovaného zbytku pohřebního přechodového rituálu nemůžeme jednoznačně vyvozovat závěry o společenském postavení každého jedince, nicméně závěr o vyšším postavení jedinců pohřbených v hrobech s výdřevou/rakví v rámci pohřbívající komunity můžeme považovat za oprávněný, tito lidé byli lépe živeni (přinejmenším z hlediska konzumace živočišných proteinů) bez ohledu na pohlaví nebo chronologii v rámci pohřebiště. U obou hrobů s mimořádnou výbavou, které leží v jižní, relativně mladší části pohřebiště v jedné řadě, je rovněž nepochybné, že žena a muž v nich pohřbení patřili k lépe postavené vrstvě komunity. O důvodech, proč se podílem živočišných proteinů nevymykají z průměru, můžeme však pouze spekulovat.

Je třeba zdůraznit, že naše zjištění by bylo problematické zobecňovat, především kvůli relativně malé velikosti sledovaného souboru, jehož poměrně homogenní strava (Kaupová a kol. v tisku) může naznačovat i nízkou sociální stratifikaci pohřbených jedinců. Ani strava jedince, ani úprava jeho pohřbu navíc nejsou př́mým důsledkem jeho sociálního postavení (Effros 2010), roli hrají i faktory individuální, co se týká stravy například chutě nebo alergie. Je také třeba mít 
na paměti, že jde jen o malou část velkého pohřebiště ve strahovské cihelně, mohla zde tedy pohřbívat skupina lidí, kteří byli něčím spojeni. Výsledky izotopové analýzy potvrdily závěry antropologického hodnocení P. Stránské (Stránská 2014a, 340-341), že se životní podmínky mužů a žen nelišily, charakteristiky jejich fyzické zátěže byly navzájem podobné a lišily se od charakteristik mužů a žen z typicky venkovských pohřebišt' v Motole a Lahovicích. Autorka tehdy došla k závěru, že obě pohlaví vykonávala práce, které se př́liš nelišily nebo nevyžadovaly zvýšený rozvoj př́slušného svalstva. Pohřbené z Trianglu tedy mohl spojovat právě druh vykonávané práce, pravděpodobně nějaké řemeslo nebo služebná činnost pro Pražský hrad.

Zkoumání stravy zemřelých nám umožňuje vykročit za hranici mrtvé kultury a nahlédnout do výseku života dávno mrtvých. S využíváním nových přírodovědných metod začínáme objevovat pestřejší škálu společenského rozvrstvení a archeologie bude muset brát více na zřetel možnost individuálních projevů vztahu pozůstalých ke svému zemřelému, jehož pohřeb neodrážel přímou úměrou jeho bohatství nebo společenské postavení.

Př́íspěvek vznik1 v rámci projektu Centra excelence GAČR 14-36938G Středověká populace v centru a na venkově. Archeologie, bioarcheologie a genetika na pohřebištích Pražského hradu, středních a východních Čech a dále za podpory Ministerstva kultury ČR, DKRVO 2018/17, Národní muzeum, 00023272.

\section{Literatura}

ADAMSON, M. W., 2004: Food in medieval times. Westport.

AMBROSE, S. H. - NORR, L., 1993: Experimental evidence for the relationship of the carbon isotope ratios of whole diet and dietary protein to those of bone collagen and carbonate. In: Prehistoric human bone (Lambert, J. B.-Grupe, G., edd.), 1-37. Berlin.

BOCHERENS, H., 1992: Biogéochimie isotopique (13C, 15N, 18O) et paléontologie des vertébrés: applications à l'étude des réseaux trophiques révolus et des paléoenvironnements. Paris.

BARRETT, J., et al., 2008: Detecting the medieval cod trade: a new method and first results, Journal of Archaeological Science 35 (4), 850-861. https://doi.org/10.1016/j.jas.2007.06.004

BORKOVSKÝ, I., 1969: Pražský hrad v době knížecí. Praha.

- 1972: Die Prager Burg zur Zeit der Přemyslidenfürsten. Praha.

DeNIRO, M. J., 1985. Postmortem preservation and alteration of in vivo bone collagen isotope ratios in relation to palaeodietary reconstruction, Nature 317 (6040), 806-809. https://doi.org/10.1038/317806a0

DeNIRO, M. J.-EPSTEIN, S., 1978: Influence of diet on the distribution of carbon isotopes in animals, Geochimica et Cosmochimica Acta 42 (5), 495-506. https://doi.org/10.1016/0016-7037(78)90199-0

- 1981: Influence of diet on the distribution of nitrogen isotopes in animals, Geochimica et Cosmochimica Acta 45 (3), 341-351. https://doi.org/10.1016/0016-7037(81)90244-1

EFFROS, B., 2010: Caring for Body and Soul: burial and the afterlife in the Merovingian world. University Park.

FROLÍKOVÁ, D., 2014: Pohřebiště z 10. století v Praze-Střešovicích - předběžná zpráva - Ein Gräberfeld aus dem 10. Jhdt. in Prag-Střešovice - vorläufiger Bericht, AH 39, 315-329.

HAKENBECK, S., 2013: Potential and limitations of isotope analysis in Early Medieval archaeology, Post-Classical Archaeologies 3, 109-125.

HAKENBECK, S., et al., 2010: Diet and mobility in Early Medieval Bavaria: a study of carbon and nitrogen stable isotopes, American Journal of Physical Anthropology 143 (2), 235-249. https://doi.org/10.1002/ ajpa.21309

KATZENBER, M. A.-WEBER, A., 1999: Stable isotope ecology and palaeodiet in the Lake Baikal region of Siberia, Journal of Archaeological Science 26 (6), 651-659.

KAUPOVÁ, S. a kol., 2018: Diet in transitory society: isotopic analysis of medieval population of Central Europe (ninth-eleventh century AD, Czech Republic), Archaeological and Anthropological Sciences 10 (4), 923-942.

KAUPOVÁ, S. a kol., v tisku: Dukes, elites, and commoners: dietary reconstruction of the Early Medieval population of Bohemia (9th-11th Century AD, Czech Republic), Archaeological and Anthropological Sciences. https://doi.org/10.1006/jasc.1998.0382 
KJELLSTRÖM, A. et al., 2009: Dietary patterns and social structures in medieval Sigtuna, Sweden, as reflected in stable isotope values in human skeletal remains, Journal of Archaeological Science 36 (12), 2689-2699. https://doi.org/10.1016/j.jas.2009.08.007

KNIPPER, C. et al., 2013: Dietary reconstruction in Migration Period Central Germany: a carbon and nitrogen isotope study, Archaeologial and Anthropological Sciences 5 (1), 17-35.

LEE-THORP, J. A., 2008: On isotopes and old bones, Archaeometry 50 (6), 925-950. https://doi. org/10.1111/j.1475-4754.2008.00441.x

LINDERHOLM, A.-KJELLSTRÖM, A., 2011: Stable isotope analysis of a medieval skeletal sample indicative of systemic disease from Sigtuna Sweden, Journal of Archaeological Science 38 (4), 925-933. https://doi.org/10.1016/j.jas.2010.11.022

LONGIN, R., 1971: New Method of Collagen Extraction for Radiocarbon Dating, Nature 230 (5291), 241242. https://doi.org/10.1038/230241a0

MINAGAWA, M.-WADA, E., 1984: Stepwise enrichment of $15 \mathrm{~N}$ along food chains: further evidence and the relation between $\delta^{15} \mathrm{~N}$ and animal age, Geochimica et Cosmochimica Acta 48 (5), 1135-1140. https:// doi.org/10.1016/0016-7037(84)90204-7

MÜLDNER, G., 2009: Investigating medieval diet and society by stable isotope analysis of human bone. In: Reflections: 50 Years of Medieval Archaeology (Gilchrist, R.-Reynolds, A., edd.), 327-346. Leeds.

OLSEN, K. C. et al., 2014: Intraskeletal isotopic compositions $\left(\delta^{13} \mathrm{C}, \delta^{15} \mathrm{~N}\right)$ of bone collagen: Nonpathological and pathological variation, American Journal of Physical Anthropology 153 (4), 598-604. https:/doi. org/10.1002/ajpa.22459

PONSARD, S.-AVERBUCH, P., 1999: Should growing and adult animals fed on the same diet show different $\delta^{15} \mathrm{~N}$ values?, Rapid Communications in Mass Spectrometry 13 (13), 1305-1310. https://doi. org/10.1002/(SICI)1097-0231(19990715)13:13<1305::AID-RCM654>3.0.CO;2-D

REITSEMA, L. J. et al., 2010: Preliminary evidence for medieval Polish diet from carbon and nitrogen stable isotopes, Journal of Archaeological Science 37 (7), 1413-1423.

REITSEMA, L. J. et al., 2017: Resilience and local dietary adaptation in rural Poland, 1000-1400 CE, Journal of Anthropological Archaeology 45, 38-52. https://doi.org/10.1016/j.jas.2010.01.001

RICHARDS, M., et al., 2006: Stable isotope palaeodietary study of humans and fauna from the multi-period (Iron Age, Viking and Late Medieval) site of Newark Bay, Orkney, Journal of Archaeological Science 33 (1), 122-131. https://doi.org/10.1016/j.jas.2005.07.003

RUTGERS, L., et al., 2009: Stable isotope data from the early Christian catacombs of ancient Rome: new insights into the dietary habits of Rome's early Christians, Journal of Archaeological Science 36 (5) 1127-1134. https://doi.org/10.1016/j.jas.2008.12.015

SALAMON, M., et al., 2008: The consilience of historical and isotopic approaches in reconstructing the medieval Mediterranean diet, Journal of Archaeological Science 35 (6), 1667-1672. https://doi.org/10.1016/j. jas.2007.11.015

SCHOENINGER, M. J.-DeNIRO, M. J., 1984: Nitrogen and carbon isotopic composition of bone collagen from marine and terrestrial animals, Geochimica et Cosmochimica Acta 48 (4), 625-639. https://doi. org/10.1016/0016-7037(84)90091-7

SLÁMA, J., 1977: Mittelböhmen im frühen Mittelalter. Praha.

STRÁNSKÁ, P., 2014: Antropologický posudek č. 1148. Uložený v archivu NZ ArÚ Praha č. TP201302614.

- 2014a: Antropologická analýza lidských kostrových pozůstatků z raně středověkého pohřebiště v Praze 6 - Stř̌ešovicích, poloha Triangl - Anthropologische Analyse menschlicher Skelettüberreste von dem frühmittelalterlichen Gräberfeld in Prag-Střešovice, Lage Triangl, AH 39, 331-345.

TESCHLER-NICOLA, M. et al., 2015: The Early Mediaeval manorial estate of Gars/Thunau, Lower Austria: An enclave of endemic tuberculosis?, Tuberculosis 95 (Supplement 1), 51-59. https://doi.org/10.1016/j. tube.2015.02.017

TOMKOVÁ, K., 2006: Příspěvek ke studiu proměn osídlení v severním a západním sousedství Pražského hradu v raném středověku, Archaeologica Pragensia 18, 203-224.

- 2006a: Raně středověká pohřebiště na předpolí Pražského hradu I. Frühmittelalterliche Gräberfelder auf dem Vorfeld der Prager Burg, Castrum Pragense 7/I.2, 5-128, 278-279.

TOMKOVÁ, K.-STRÁNSKÁ, P., 2011: K nestandardním projevům pohřebních aktivit na předpolí Pražského hradu - On non-standard manifestation of funerary activities in the foreground of Prague Castle, ASČ $15,553-561$.

Van KLINKEN, G. J., 1999: Bone collagen quality indicators for palaeodietary and radiocarbon measurements, Journal of Archaeological Science 26 (6), 687-695. https://doi.org/10.1006/jasc.1998.0385

VIKA, E.-THEODOROPOULOU, T., 2012: Re-investigating fish consumption in Greek antiquity: results from $\delta^{13} \mathrm{C}$ and $\delta^{15} \mathrm{~N}$ analysis from fish bone collagen, Journal of Archaeological Sciences 39 (5), 16181627. https://doi.org/10.1016/j.jas.2012.01.016 
WATERS-RIST, A.-KATZENBERG, M., 2010: The effect of growth on stable nitrogen isotope ratios in subadult bone collagen, International Journal of Osteoarchaeology 20 (2), 172-191.

YODER, C., 2012: Let them eat cake? Status-based differences in diet in medieval Denmark, Journal of Archaeological Science 39 (4), 1183-1193. https://doi.org/10.1016/j.jas.2011.12.029

\section{Zusammenfassung}

\section{Die auf dem Gräberfeld Triangel in Prag-Střešovice bestattete Population im Hinblick auf die Rekonstruktion der Ernährung}

Die im 10. Jahrhundert in Sichtweite der Prager Burg lebende und bestattende Population (Abb. 1) wurde sowohl von archäologischer (Frolíková 2014, 315) als auch von anthropologischer Seite her (Stránská 2014, 331) veröffentlicht. Die Ernährung der Population wurde mithilfe der Methode einer Isotopenanalyse von Knochenproben von neunzehn erwachsenen Individuen untersucht, bei denen das Geschlecht anthropologisch geschätzt wurde (Abb. 2). In dem Komplex sind Männer und Frauen ungefähr gleichmäßig vertreten (9:10). Bei einem Blick auf die Planskizze des Gräberfeldes ist der Unterschied zwischen einer Reihenanordnung des südlichen Teils des Gräberfeldes, in dem eine SW-NO-Orientierung überwiegt, und dem nördlichen Teil auffällig, in dem die Gräber unregelmäßig angelegt wurden und eine überwiegende W-O-Orientierung aufweisen. Aufgrund der Störung des älteren Grabes 2 mit W-O-Orientierung durch die jüngeren Gräber 34 und 37 mit SW-NO-Orientierung zeigt sich der chronologische Unterschied als mögliche Erklärung, da auch die Orientierung der Grabgruben einer der untersuchten Aspekte war. Im Hinblick darauf, dass der soziale Status der Bestatteten möglicherweise zum Ausdruck kommt, wurde von uns berücksichtigt, ob ein Grab über Grabbeigaben verfügte oder nicht, bzw. auch, wie anspruchsvoll die Grabgruben hergerichtet waren, was insbesondere durch ihre Abmessungen in Verbindung mit der Verschalung bzw. den Särgen zum Ausdruck kam. Zu Vergleichszwecken werden auch in die Gräber gelegte Steine herangezogen, die jedoch eine anspruchslose Art und Weise der Grabgrubenherrichtung darstellen (Tab. 1). Der Komplex an der Fundstelle Triangel weist - im Hinblick auf die mittelalterliche Population - in ihrer Gesamtheit einen durchschnittlichen Anteil von tierischen Proteinen in der Ernährung und einen signifikanten Konsum von Hirse auf. Die Isotopwerte (besonders $\delta^{13} \mathrm{C}$ ) sind von geringer Variabilität, was auf eine homogene Ernährung des untersuchten Komplexes hindeutet. Das Fehlen von statistisch signifikanten Ergebnissen kann nicht eindeutig durch den geringen Grad der sozialen Stratifikation erklärt werden. Man muss erwähnen, dass dies eine Folge der geringen Größe des untersuchten Komplexes sein kann. Sowohl die Ernährung eines Individuums, als auch die Herrichtung seiner Beisetzung kann auch durch eine Reihe von individuell verursachten Faktoren beeinflusst worden sein, im Falle der Ernährung beispielsweise durch den individuellen Geschmack oder durch eine Allergie. Und die Ernährung von reicheren Individuen konnte sich letztendlich durch einen höheren Gehalt von im Isotopensignal nicht erfassbaren Nahrungsmitteln unterscheiden (z. B. Obst, Nüsse, Alkohol). Für einen geringeren Grad der sozialen Stratifikation im Rahmen des Komplexes spricht auch die im Vergleich zu anderen Fundstellen verhältnismäßig homogene Ernährung (Kaupová a kol. im Druck). Die Analyse der Nahrung hat keinen statistisch signifikanten Bezug zwischen der Qualität der Ernährung und der Grabausstattung als potenzieller Indikator für den sozioökonomischen Status eines Individuums ergeben (Tab. 2, Abb. 3). Das mit den reichsten Beigaben ausgestattete Frauengrab 47 sowie das mit Sporen versehene Männergrab 40 zählen gemäß dem Anteil des Konsums von tierischen Proteinen im Rahmen der analysierten Probe von dem Gräberfeld zur unteren Hälfte, umgekehrt weisen die Gräber ohne Beigaben zusammen mit dem mit einem Messer versehenen Grab 36 den höchsten Anteil an Proteinen in der Ernährung auf. Die Situation verhält sich anders, wenn wir zwischen der Herrichtung einer Grabgrube und der Qualität der Nahrung einen Bezug herstellen: Gräber mit dem verzeichneten Vorhandensein von Holz (mit Ausnahme von Grab 40) häufen sich in der 
oberen Hälfte des Diagramms, zusammen mit ihnen gibt es dort das gestörte Vierergrab 22. Von dem archäologisierten Rest des Übergangsrituals von Bestattungen können wir keine eindeutigen Schlussfolgerungen über die gesellschaftliche Stellung eines jeden Individuums ableiten, nichtsdestotrotz können wir den Schluss einer höheren Stellung von Individuen als berechtigt zulassen, die im Rahmen der in der Lage Triangel bestatteten Kommunität in Gräbern mit Verschalung/Särgen bestattet wurden, diese Personen hatten ungeachtet des Geschlechts oder der Chronologie im Rahmen des Gräberfeldes eine bessere Ernährung. Bei den beiden mit außerordentlicher Ausstattung versehenen Gräbern, die im südlichen, relativ jüngeren Teil des Gräberfeldes in einer Reihe liegen, ist es ebenfalls ohne Zweifel, dass die darin bestattete Frau und der Mann zur besser gestellten Schicht der Kommunität gehörten. Über die Gründe, warum sie sich mit dem Anteil an tierischen Proteinen nicht vom Durchschnitt abheben, können wir jedoch lediglich Spekulationen anstellen.

Der vorliegende Beitrag entstand im Rahmen des Projektes Center of excellence GAČR 14-36938G Die mittelalterliche Population im Zentrum und auf dem Land. Archäologie, Bioarchäologie und Genetik auf den Gräberfeldern der Prager Burg, Mittel- und Ostböhmens, sowie ferner unter der Förderung des Ministeriums für Kultur der Tschechischen Republik DKRVO 2018/17, Nationalmuseum, 00023272.

PhD. Drahomíra Frolíková-Kaliszová, Ph.D., Archeologický ústav AV ČR, Praha, v. v. i., Letenská 4, 11801 Praha 1, Česká republika

Mgr. Sylva Kaupová, Ph.D., Antropologické oddělení Národního muzea, Václavské nám. 68, 11000 Praha 1, Česká republika 
